\title{
LICHENS OF BUTTONGRASS (GYMNOSCHOENUS) MOORLAND IN TASMANIA
}

\author{
by G. Kantvilas and S. J. Jarman
}

(with three tables and one text-figure)

KANTVILAS G. \& JARMAN, S. J., 1988 (31:x): Lichens of buttongrass (Gymnoschoenus) moorland in Tasmania.

\begin{abstract}
Fap. Proc. $R$. Soc. Tasm. 122(2): 1-17. https://doi.org/10.26749/rstpp.122.2.1 ISSN 0080-4703. Tasmanian Herbarium, University of Tasmania, G.P.O. Box 252C, Hobart, Australia 7001, formerly Tasmanian Department of Lands, Parks and Wildlife (G.K.); Department of Lands, Parks and Wildlife, Macquarie Street, Hobart, Tasmania, Australia 7000, formerly Department of Botany, University of Tasmania (S.J.J.).
\end{abstract}

Eighty-nine lichen species are recorded from buttongrass (Gymnoschoenus) moorland in Tasmania. Of these, Hypocenomyce australis, Ochrolechia frigida, Placynthium nigrum, Protoblastenia rupestris, Siphulastrum triste and Trapeliopsis colensoi are new records for Tasmania. Over $70 \%$ of the species have Southern Hemisphere distributions, analogous to that of the majority of the vascular flora. However, $25 \%$ of the species also occur in the Northern Hemisphere, mostly in ecologically related blanket bogs or moors. A preliminary classification of lichens in twelve broad moorland vegetation types is presented. Favoured habitats for lichens include peat, rotting sedge tussocks or stumps, loose stones and large rock outcrops. Although most moorland lichen species are widespread in other Tasmanian vegetation formations, repeated, frequent fires are seen as a major threat to their long-term survival within the moorland ecosystem.

Key Words: lichens, moorland, Tasmania.

\section{INTRODUCTION}

Buttongrass moorland comprises vegetation associated with the sedge Gymnoschoenus sphaerocephalus, colloquially known as buttongrass. The vegetation occupies approximately $15 \%$ of the total area of Tasmania (see Duncan 1985), with its greatest representation occurring in the western half of the island (fig. 1). It is found mainly within the $1600 \mathrm{~mm}$ isohyet (Gellie 1980) and ranges in altitude from sea level to c. $1000 \mathrm{~m}$. It also occurs in Victoria and New South Wales where it is comparatively poorly represented, both in area and diversity.

The vegetation can be divided into two basic types. The most extensive of these is found mostly in southwestern and western Tasmania. It occurs on shallow peats across hilly terrain and is analogous to the blanket bogs of the Northern Hemisphere. It also includes small acidic or alkaline outwashes on mineral soils (mainly sand) but these represent only a very small proportion of the vegetation. The second type is found in the central and northeastern highlands and in lowlands in northwestern, northeastern and southern Tasmania, with small outliers on the west coast. This vegetation is found mostly in depressions or flat areas but sometimes extends onto very gently undulating terrain. It occurs on either peaty or mineral soils, the latter including loams, sandy loams and light clays.

Buttongrass moorland consists of sedgelands, heathlands, graminoid heathlands and scrub which often form a complex mosaic, particularly in the blanket bogs. They are very inflammable and have a long history of accidental and deliberate burning. The latter has been undertaken officially for habitat management or fuel reduction near property or forests. Arson is also a cause of many fires.

Important angiosperm families present include the Cyperaceae (Gymnoschoenus, Lepidosperma, Baumea, Schoenus), Restionaceae (Restio, Empodisma, Lepyrodia, Leptocarpus), Epacridaceae (Epacris, Sprengelia), Proteaceae (Banksia, Agastachys, Hakea) and the Myrtaceae (Leptospermum, Melaleuca, Baeckea). The main pteridophytes are Selaginella, Lycopodium, Gleichenia and Lindsaea. The most common or widespread bryophytes are Goebelobryum unguiculatum, Dicranoloma billardieri, Campylopus introflexus and C. kirkii.

Lichens are often a conspicuous component of buttongrass moorland and, in some communities, may comprise the dominant ground cover. Despite this, the lichen flora has never been studied in detail, although brief, incomplete species lists are given by Bratt $(1976,1978)$. The present paper 


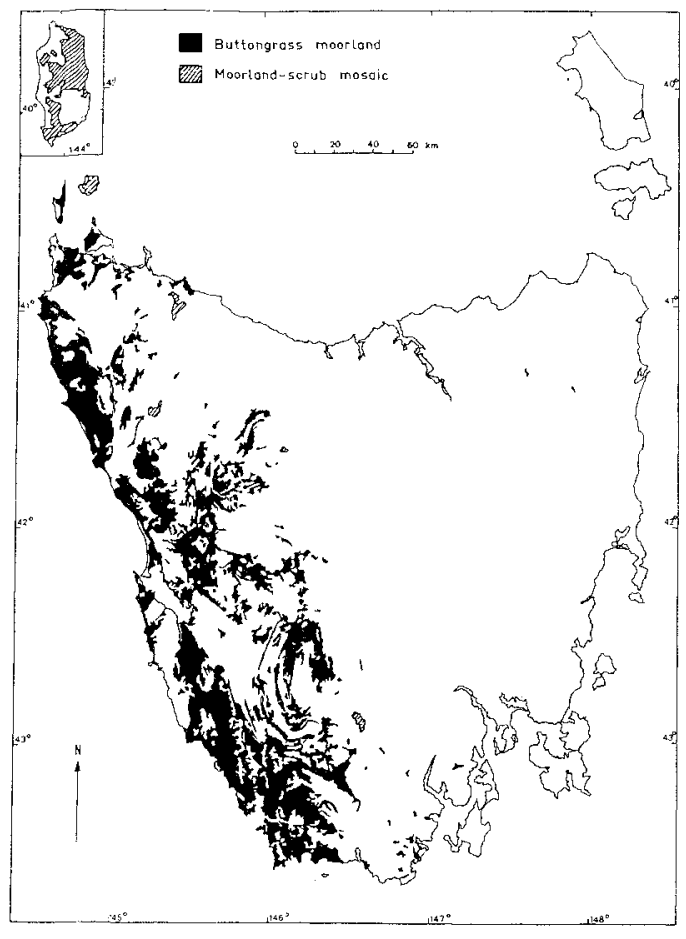

FIG. I -- The distribution of buttongrass moorland and moorland-scrub mosaic in Tasmania (after Kirkpatrick \& Dickenson 1984).

reports on the lichens recorded during a general botanical survey of buttongrass moorland in Tasmania (Jarman et al., in prep.) and discusses their ecology and distribution.

\section{METHODS}

The survey was limited to vegetation containing Gymnoschoenus (ecotones excluded), and to the small, recurring islands or strips of sedgeland, heathland and scrub which are surrounded by Gymnoschoenus communities and which form an integral part of the overall moorland landscape. The upper altitudinal limit of the survey was c. $1000 \mathrm{~m}$, i.e. the upper limit of Gymnoschoenus.

The emphasis of the study was on terricolous species which comprise the main lichenological component of buttongrass moorland. Because of time constraints, studies of saxicolous species were limited to the more common, conspicuous of characteristic species. Similarly, the study of epiphytic lichens was limited to those considered characteristic of buttongrass moorland. Isolated large trees or copses occasionally serve as refugia for lichens from other vegetation formations (e.g. rainforest) but these species have not been included.

Presence/absence data for lichens were obtained from over 450 quadrats $(5 \times 5 \mathrm{~m})$ which formed the basis of the classification of angiosperm communities (Jarman et al. in prep.). The quadrats were located subjectively to cover the structural, floristic, altitudinal and geographical range of the vegetation. Supplementary observations from adjacent or related vegetation provided an overview for the survey.

\section{RESULTS}

\section{General Description}

Eighty-nine lichens in 42 genera are recorded from buttongrass moorland in Tasmania. These are listed in the appendix with notes on their distribution and ecology. They include 74 macrolichens and 15 crustose species, although the latter can be expected to increase significantly with further work. Two additional, undescribed macrolichens of uncertain generic affinities were also recorded and will be treated in forthcoming papers. Two species, Multiclavula vernalis and Omphalina sp., are basidiolichens whilst the remainder are ascolichens or lichenes imperfecti. Several species, including Hypocenomyce australis, Lithographa sp., Ochrolechia frigida, Placynthium nigrum, Protoblastenia rupestris, Siphulastrum triste and Trapeliopsis colensoi, are new records for Tasmania.

Major genera with respect to diversity and/or abundance include Cladonia (23 species), Cladia (7 species) and Siphula (4 species), and together these comprise the core of the lichen flora. Xanthoparmelia ( 8 species) is dominant on many large rock outcrops. Additional common genera include Hypogymnia, Lecidea s.lat. and Menegazzia (on rocks or epiphytic), Cladina (on soil) and Umbilicaria (on rocks).

A few species, e.g. Cladia inflata, $C$. moniliformis, Micarea sp., Multiclavula vernalis, Pycnothelia caliginosa and Siphula jamesii are mainly confined to buttongrass moorland but most others are widespread outside of this vegetation. 
The low proportion of lichens peculiar to buttongrass moorland may be attributed in part to the character of the vegetation, in so far as it often forms a mosaic with other formations such as sclerophyll forest, rainforest and alpine vegetation. The close proximity of these formations enables many of the ecologically wide-ranging lichens to spread into buttongrass moorland.

Within the moorland, the majority of lichens present are restricted to specialised niches or communities and their distribution patterns are consistent with their range in other vegetation types. For example, species from heathlands are mostly confined to shrubby moorland communities whilst species from alpine vegetation are found mostly in high altitude moorland. Only very few lichens, e.g. Cladia aggregata and Cladonia southlandica, are widespread across a broad range of the vegetation.

More than half $(55 \%)$ of the species recorded are terricolous. Peat is the most common substrate available and supports species usually found on mineral soil, e.g. Cladonia corniculata, as well as those characteristic of rotting wood or litter, e.g. $C$. weymouthii and $C$. subdigitata. Most peats and soils in buttongrass moorland have a $\mathrm{pH}=4-4.5$ (Tarvydas 1978, unpubl. data). However, some communities, particularly in southwestern Tasmania, contain open sandy or silty outwashes or pans where the $\mathrm{pH}$ can be as high as 9 and there is a concomitant change in the vascular flora (Brown et al. 1982). Terricolous lichens are absent from such sites although this could be due to factors other than $\mathrm{pH}$. The pans are often poorly drained, periodically inundated and their fine sand or silt is not colonised by lichens even where the $\mathrm{pH}$ is low. Very depauperate lichen thalli are usually present at the margins of the pans on mounds of peat.

Well-drained, well-lit habitats are most favourable for lichen growth in buttongrass moorland. Rotting Gymnoschoenus hummocks provide an ideal substrate above the matrix of sedges and shrubs but gaps between hummocks are also colonised. The most common lichens include Cladia aggregata, C. inflata, $C$. retipora, $C$. sullivanii, Siphula decumbens, Cladonia southlandica and $C$. subsubulata, the last two species often occurring only as mats of squamules. All these species generally become depauperate in very moist, shaded sites which tend to be favoured by bryophytes. However, some lichens do occur in well-lit, boggy sites and these include Siphula jamesii, Multiclavula vernalis and the grotesquely inflated species, Cladia moniliformis. At high altitudes, Siphula complanata and S. fragilis are locally abundant in and around shallow, muddy puddles.

Lichens increase in diversity in some of the more shrubby buttongrass communities where the peat is more fibrous and better drained. Cladonia in particular becomes abundant, with additional species such as $C$. campbelliana, $C$. capitellata, $C$. cervicornis spp. verticillata, $C$. corniculata, $C$. praetermissa, $C$. pyxidata, $C$. subdigitata and $C$. weymouthii locally common. Knightiella splachnirima, Trapeliopsis colensoi and Cladina confusa also occur primarily in such vegetation. Some communities commonly include open areas between shrubs and sedge hummocks where lichens form a diverse, extensive mat, interspersed with low angiosperms such as Hibbertia procumbens and Schoenus tenuissimus.

As the moorlands age, several communities, particularly those with a significant shrub component, ultimately produce a closed canopy of woody species. In many cases, the lichens are affected adversely, in a manner similar to that described by Gimingham (1960) for Calluna heaths in the Northern Hemisphere where lichens are eliminated as the shrubbery grows denser. However, in other situations, lichens remain well represented in the vegetation and may even increase in biomass and diversity (cf. Coppins \& Shimwell (1971) on British heathlands). Most shrubs in Tasmanian moorland have fine foliage which allows light to filter through to the ground. This light is apparently insufficient to maintain a vigorous ground layer of angiosperms and in some sites, canopy closure of the dominant species (e.g. Leptospermum or Melaleuca spp.) has all but eliminated Gymnochoenus and other sedges. The resulting ground layer is dominated instead by mosses (e.g. Ptychomnion aciculare) and lichens which include typical moorland species as well as some more characteristic of open forest, e.g. Cladonia gracilis ssp. tenerrima, C. ochrochlora, C. scabriuscula and Peltigera dolichorhiza. In some very old communities (to c. 70 years), canopy closure does not occur and a pattern of large, widely-spaced shrubs and sedges is maintained, interspersed with mats of Cladonia and Cladia species. In such cases, the lichens may be inhibiting the establishment of angiosperm species; evidence for such an effect has been presented from Northern Hemisphere heathlands by Hobbs (1985).

On steep slopes, mostly in southwestern Tasmania, extensive areas of gravel and small stones are exposed where the peat surface has been largely removed by erosion or fire. Terricolous lichens become very restricted although Micarea 
sp. is locally abundant and serves to stabilise the remnans of peat. The gravel supports several inconspicuous crustose lichens, e.g. Lithographa sp. and species of Lecideaceae s.lat., particularly Lecidea leptocarpa aggr.

Large rock outcrops are a common feature of the buttongrass moorland landscape, particularly in western Tasmania. They act as islands of diversity in an otherwise lichenologically rather depauperate vegetation by providing a wide range of microhabitats as well as some degree of fireprotection. Several rock types are-represented including conglomerate, dolerite, basalt, granite, limestone and Precambrian metamorphic rocks. The last type tends to support the most diverse lichen flora. Limestone has a particularly depauperate but very characteristic lichen flora which includes Placynthium nigrum, Protoblastenia rupestris and several as yet unidentified species of Lecideaceae s.lat. Dominant species on rock outcrops include species of Parmeliaceae, e.g. Parmelia signifera, Flavoparmelia haysomii, Hypotrachyna sinuosa and Xanthoparmelia spp., of which $X$. mougeotina is the most common and widespread. Other common species include Rhizocarpon cf. geographicum, Lecidea coromandelica and Protoparmelia petraeoides. Apices of the rocks are often crowned with tufts of Usnea torulosa whilst Cystocoleus niger colonises the sheltered sides. Rock outcrops in coastal or lowland areas may support species of Heterodermia. At high altitudes, additional lichens such as Neofuscelia stygioides, Parmelia signifera, Menegazzia aeneofusca and Umbilicaria spp. are also present, but these may range to sea level on Precambrian rocks in southwestern Tasmania. Several typical rainforest epiphytes also occur on the outcrops and may represent relics from a time when rainforest was more extensive over the present-day range of buttongrass moorland. Examples include Sphaerophorus tener, $S$. melanocarpus and Megalospora lopadioides, as well as the vascular species, Apteropteris applanata, Hymenophyllum spp. and Prionotes cerinthoides.

Peat-filled crevices in the rock outcrops commonly abound with lichens, including Cladia spp., Siphula decumbens and several Cladonia spp., e.g. C. capitellata, $C$. chlorophaea and $C$. pleurota. Less widespread species include Gymnoderma melacarpum, Ochrolechia frigida and Wawea fruticulosa. The outcrops are usually surrounded by vegetation more shrubby than the local moorland and hence there also tends to be a greater diversity of terricolous species in the general vicinity of these rocks.
Epiphytic species are poorly developed in buttongrass moorland, mainly due to a paucity of substrates since the shrubs present rarely attain sufficient size or age to support diverse assemblages of epiphytes. Lecidea laeta is common on the twigs of myrtaceous shrubs whilst Usnea arida, Lecidella elaeochroma, Menegazzia platytrema, Hypogymnia turgidula and Hypotrachyna sinuosa are common on emergent trees or large shrubs of Banksia, Hakea or Casuarina. Dense, very wet copses of Melaleuca often support Wawea fruticulosa. Catillaria sp. is common on decorticated trunks of Eucalyptus whilst rotting stumps and logs are colonised by Cladia schizopora, Cladonia squamosula and $C$. subdigitata. Charred wood supports Hypocenomyce australis and, in low rainfall areas, Thysanothecium scutellatum. Some shrubby buttongrass moorland communities are precursors in the succession to scrub and forest (Jackson 1968) and hence may ultimately develop diverse epiphytic floras, more akin to sclerophyll forest or rainforest (see Kantvilas et al. 1985).

Irrespective of species abundance, the lichen flora of buttongrass moorland is generally very depauperate in comparison with that of other Tasmanian vegetation. Few of the sample sites contained more than 5-6 species and although more than 80 lichens were recorded overall, many of these represent incidental occurrences of species which attain their peak development elsewhere. Even the characteristic moorland species such as Siphula decumbens, Cladia aggregata, C. retipora, $C$. sullivanii and the Cladonia species are widespread in other vegetation types. The overall low number of species in buttongrass moorland suggests that lichens have been unable to exploit the particular conditions prevailing there and hence the flora is comprised essentially of wide-ranging opportunistic species.

\section{Distribution}

The majority of lichens in buttongrass moorland are widespread in Tasmania and many apparent regional differences (table 1) disappear when occurrences of the lichens in other vegetation types are considered. However, within the moorland lichen flora, there is a marked difference between southwestern Tasmania and the remainder of the island. This difference is also evident in the vascular flora. Lichens mostly confined to southwestern Tasmania include Multiclavula vernalis, Pycnothelia caliginosa, Lithographa sp., Cystocoleus niger, Micarea sp., Pertusaria sp., 
TABLE 1

Frequency of Terricolous Lichens in 12 Classes of Buttongrass Moorland Vegetation*

\begin{tabular}{|c|c|c|c|c|c|c|c|c|c|c|c|c|c|}
\hline \multirow{2}{*}{$\begin{array}{l}\text { Species } \\
\text { groups }\end{array}$} & \multirow[t]{2}{*}{ Species } & \multicolumn{12}{|c|}{ Vegetation groups** } \\
\hline & & 1 & 2 & 3 & 4 & 5 & 6 & 7 & 8 & 9 & 10 & 11 & 12 \\
\hline \multirow[t]{6}{*}{1} & Cladia aggregata & 0 & 0 & * & $x$ & $\mathrm{x}$ & $\mathrm{x}$ & $x$ & $x$ & $\ddagger$ & $\mathrm{x}$ & o & + \\
\hline & Cladonia southlandica & + & 0 & + & $\ddagger$ & o & $\ddagger$ & $\ddagger$ & $\mathrm{x}$ & - & $\dot{\ddagger}$ & 0 & - \\
\hline & Cladia retipora & & 0 & - & $\ddagger$ & 本 & $x$ & 李 & $\neq$ & + & o & + & - \\
\hline & Cladonia subsubulata & - & - & - & + & o & 0 & $\ddagger$ & 0 & - & 0 & + & - \\
\hline & Cladina confusa & - & - & - & + & + & o & 0 & + & - & - & - & - \\
\hline & Cladonia capitellata & - & - & - & - & + & o & o & $o$ & o & o & - & - \\
\hline \multirow[t]{4}{*}{2} & Siphula jamesii & - & - & + & 0 & o & - & - & - & - & - & - & - \\
\hline & Micarea sp. & - & - & - & o & o & - & - & - & - & - & - & - \\
\hline & Multiclavula vernalis & + & + & + & - & + & - & - & - & - & - & - & - \\
\hline & Cladia moniliformis & o & o & 韦 & $\mathrm{x}$ & $x$ & - & - & - & - & + & - & - \\
\hline \multirow[t]{5}{*}{3} & Cladia fulignosa & - & - & - & - & + & - & - & - & - & - & - & - \\
\hline & Pertusaria sp. & - & - & - & - & o & - & - & - & - & - & - & - \\
\hline & Cladina mitis & - & - & - & - & + & - & - & - & - & - & - & - \\
\hline & Wawe a fruticulosa & - & - & - & - & + & + & - & - & - & - & - & - \\
\hline & Pycnothelia caliginosa & - & - & - & - & + & - & - & - & - & - & - & - \\
\hline \multirow[t]{4}{*}{4} & Siphula decumbens & - & - & o & $x$ & $x$ & $\ddagger$ & o & - & - & - & - & - \\
\hline & Cladonia murrayi & - & - & - & + & 0 & 0 & o & - & - & - & - & - \\
\hline & Cladia sullivani & - & + & - & o & $\ddagger$ & 末 & $\dot{\ddagger}$ & o & - & - & - & - \\
\hline & Siphula fragilis & - & - & - & + & o & - & 0 & - & - & - & - & - \\
\hline \multirow[t]{13}{*}{5} & Cladonia weymouthii & - & - & - & - & - & o & + & + & + & - & - & - \\
\hline & Cladonia subdigitata & - & - & - & - & - & 0 & o & + & + & - & - & - \\
\hline & Cladonia ochrochlora & - & - & - & - & - & o & - & + & o & - & - & - \\
\hline & Cladonia cervicornis & & & & & & & & & & & & \\
\hline & subsp. verticillata & - & - & - & - & - & + & o & 0 & 0 & - & - & - \\
\hline & Cladonia corniculata & - & - & - & - & - & - & o & o & o & o & - & - \\
\hline & Cladonia gracilis & & & & & & & & & & & & \\
\hline & subsp. tenerrima & - & - & - & - & - & + & - & + & o & - & - & - \\
\hline & Cladonia pleurota & - & - & - & - & - & + & o & + & - & - & - & - \\
\hline & Cladonia squamosula & - & - & - & - & - & o & 0 & o & - & - & - & - \\
\hline & Cladonia ramulosa & - & - & - & - & - & + & - & o & - & - & - & - \\
\hline & Knightiella splachnirima & - & - & - & - & - & 0 & o & o & - & - & - & - \\
\hline & Cladia schizopora & - & - & - & - & - & + & - & o & - & - & - & - \\
\hline \multirow[t]{5}{*}{6} & Omphalina sp. & - & - & - & - & - & - & o & - & o & - & - & - \\
\hline & Trapeliopsis colensoi & - & - & - & - & - & - & 0 & - & 0 & - & - & - \\
\hline & Cladonia pyxidata & - & - & - & - & - & - & 0 & - & o & - & - & - \\
\hline & Cladonia tessellata & - & - & - & - & - & - & o & - & - & - & - & - \\
\hline & Siphula complanata & - & - & - & - & - & - & 0 & - & - & - & - & - \\
\hline \multirow[t]{5}{*}{7} & Cladonia campbelliana & - & - & - & - & & - & o & o & - & - & - & - \\
\hline & Cladonia wilsonii & - & - & - & - & - & - & + & + & - & - & - & - \\
\hline & Cladonia chlorophaea & - & - & - & - & - & - & o & + & - & - & - & - \\
\hline & Cladonia praetermissa & - & - & - & - & - & - & - & o & - & - & - & - \\
\hline & Cladonia angustata & - & - & - & - & - & - & - & + & - & - & - & - \\
\hline \multicolumn{2}{|c|}{ Number of sites } & 25 & 40 & 12 & 50 & 40 & 20 & 10 & 33 & 10 & 8 & 55 & 5 \\
\hline
\end{tabular}

* Descriptions of vegetation and species groups are given in tables 2 and 3 respectively.

$* * x$ denotes frequency $>80 \%,+50-80 \%, 010-15 \%,+<10 \%$. 
Siphula jamesii and Cladia moniliformis. Lichens occurring mostly outside the southwest include Thysanothecium scutellatum, Cladonia angustata and $C$. praetermissa, but these are essentially dry sclerophyll forest species occurring opportunistically in moorland. Some lichens show regional distributions in the lowlands but become ubiquitous at higher altitudes (above c. $750 \mathrm{~m}$ ). For example, in the lowlands, Siphula decumbens is a characteristic southwestern species and Cladonia subsubulata is characteristic of non-southwestern communities but, at high altitude, both are widespread throughout Tasmania.

Several species are confined to high altitudes and their occurrence in buttongrass moorland usually represents the lowest limits of their range, e.g. Cladia fuliginosa, Cladina mitis, Siphula fragilis, S. complanata, Siphulastrum triste and Ochrolechia frigida. However, altitudinal distinctions become blurred in the southwest where many high altitude lichens, particularly saxicolous species such as Umbilicaria spp. and Neofuscelia stygioides, extend to sea level. Several alpine angiosperms exhibit a similar distribution pattern. This effect of depressed altitude further contributes to the distinctiveness of the flora of southwestern Tasmania.

In addition to changes in composition, the lichen flora tends to increase in biomass at high altitude with Cladia sullivanii, $C$. retipora, Cladonia capitellata and Cladina confusa becoming particularly well developed. Other species, e.g. Cladonia campbelliana, $C$. pleurota, C. pyxidata, $C$. subdigitata, $C$. tessellata, $C$. weymouthii and Menegazzia aeneofusca, also become more common, However, our observations indicate that these species are capable of proliferating at all altitudes. Their comparatively poor development and scarcity in the lowlands may be due at least partly to fire history. In general, the lowland moorlands have been burnt more frequently than highland moorlands, resulting in the virtual elimination of much of their lichen flora.

\section{Relationships with Higher Plant Floristics}

The relationships between 12 vascular plant groups in buttongrass moorland and their constituent lichens are summarised in table 1. These groups, described briefly in table 2 , are based on the communities described by Jarman et al. (in prep.) but several related communities with similar floristic, geographical, altitudinal or structural characteristics have been combined. Twe of the groups (numbers 9 and 12 in table 2), representing Sphagnum bogs and high altitudo grasslands respectively, are not strictly buttongrass moorland vegetation but often contain Gymnoschoenus at their boundaries. Lichen species have been classified into seven groups which are described in table 3. Only terricolous species (or those on the ground on rotting wood etc.) are included. Saxicolous and epiphytic lichens are omitted because their occurrence depends on the presence of large rocks or trees rather than directly on the nature of the host vegetation. The data presented in table 1 relate specifically to the occurrence of lichens in buttongrass moorland and apparent patterns may alter if distributions in other vegetation types are considered.

The results from table I support many of the geographical, altitudinal and ecological trends already discussed. For example, the floristic distinctions between buttongrass moorland in southwestern Tasmania (groups 1-6) and elsewhere (groups 7-12) are clearly evident, with lichens from species groups 2-4 characterising the former. However, there is a similarity between southwestern shrubby copses (group 6) and heathlands elsewhere in Tasmania (groups 7-8) as exemplified by the lichens in species group 5 . These vegetation groups (numbers 6-8) also have many vascular plants in common. The substantially greater diversity of lichens in well-drained, shrubby communities (vegetation groups 4-8) in comparison with dense sedgy or very wet communities $(1-3,10-11)$ is also well illustrated, with all but a few lichens from species group 1 (the ubiquitous species) being confined to the former. Lichens are particularly depauperate in high altitude grassland (group 12) where the dense ground layer of herbs excludes their colonisation. They are also relatively impoverished in Sphagnum bogs where they are unable to colonise actively growing Sphagnum mounds (cf. Foster 1984, for raised bogs in Canada). However, lichens may develop locally on dead or fire-scorched Sphagnum or rotting wood. Emergent Richea spp. in this community support a diverse epiphytic flora of essentially rainforest species.

\section{Effects of Fire}

The majority of lichens from buttongrass moorland are very sensitive to fire and are easily destroyed. Not only are the species killed outright but their habitat, especially the peat substrate, can 
severely damaged. Thus repeated occurrence of ire at short intervals can be expected to result in a narked loss of diversity, reducing the flora to a few, ubiquitous, rapidly colonising species. The nost fire-tolerant lichens appear to be Cladonia southlandica, Cladia aggregata, $C$. inflata and, to a lesser extent Cladonia subsubulata and Siphula decumbens. Instances where depauperate thalli of hese specics have re-established (in the case of Cladonia as basal squamules only) c. 2-5 years after a fire have been observed. However, it is difficult to imagine how thalli of this type could survive repeated burning at short intervals. Thus with high fire frequencies the long-term survival of even the most fire-tolerant species is doubtful. On a very local scale in some very dense communities, occasional fires may aid the establishment of lichens by opening up the vegetation, a situation akin to that described for Calluna heaths by Gimingham (1978) and Hobbs (1985).

In addition to fire frequency, lichen recovery seems dependent on the intensity of the fire. For example, scorched Cladonia squamules often remain after a fire although it is not clear to what extent they are still viable. It is also possible that the underground rhizines of Siphula could survive fire provided the peat is only scorched at the surface rather than stripped of its uppermost layers. Recovery may also depend on "site quality". Observations from adjacent sites in buttongrass moorland which have been burnt simultaneously indicate that lichens as well as most shrub species tend to re-establish sooner and grow faster in heathlands or copses than in graminoid communities.

Large rock outcrops in buttongrass moorland can provide some protection from fire and serve as sources of recolonisation. However, repeated burning of an area increases the chances of ultimately eliminating even these refugia. Saxicolous species on exposed surfaces are easily lost and are slow to recover on scorched rock, whilst burning and erosion of peat in crevices leads. to a loss of terricolous species through the destruction of their habitat.

The long-term result of fire in Tasmania's buttongrass moorland is difficult to predict. On the one hand, lichens are clearly very fire-sensitive. On the other, they have managed to survive in buttongrass moorland up to the present time despite the fact that fire has been a repeated occurrence in the vegetation throughout its history. Given the present policy in Tasmania of frequent fuel reduction burning, it seems inevitable that in some areas, lichens will become locally extinct because their recolonisation after one fire will scarcely have begun before another fire destroys their new growth. This situation is analogous to that described for British moors which are burnt regularly for grouse and sheep management and where most lichens have been eliminated (Gilbert 1980a, b, Hawksworth 1969). In order to avoid large-scale extinction in Tasmania, it seems of critical importance to preserve a diversity of vegetation ages and types so that some refugia for lichens will always be maintained.

\section{Phytogeography}

Over $70 \%$ of the lichens recorded from buttongrass moorland have predominantly Southern Hemisphere distributions, similar to the distributions of much of the vascular flora (e.g. the Restionaceae, Proteaceae and Epacridaceae). Approximately one-third of these lichens comprise genera and species confined to or centred in the far south of the Southern Hemisphere (Tasmania, New Zealand, southern South America) and can be referred to as "austral cool temperate" (after Jørgensen 1983). Examples (include the genera Siphula, Knightiella, Menegezzia, Placopsis and Siphulastrum, as well as the species Cladonia murrayi, C. corniculata, Hypogymnia lugubris, Neofuscelia stygioides, Trapeliopsis colensoi and Wawea fruticulosa. The remainder have more "warm temperate" (Jørgensen 1983) or "Australian" (after Galloway 1979) distributions, e.g. Cladia, Thysanothecium, Xanthoparmelia, Cladonia augustata, $C$. capitellata, $C$. kuringaiensis, C. southlandica, Hypocenomyce australis, Protoparmelia petraeoides, Parmelia signifera and Usnea torulosa. The large endemic element in the vascular flora (c. $30 \%$ ) is not evident in the lichens, with only Siphula jamesii, Cladia moniliformis and Micarea sp. being endemic to Tasmania. However, additional endemics are likely to be found amongst the undescribed taxa.

Despite this essentially "southern" nature of the lichen flora, there are many similarities between Tasmanian buttongrass moorland and analogous blanket bogs and moors in the Northern Hemisphere, particularly Britain. For example, the generic composition of the two lichen floras is similar, with Cladonia and Cladina constituting a major component of both (see Gilbert (1974), Watson (1932) for data on Britain). Similarly species of Lecidea s. lat. comprise much of the flora on small stones whilst Parmelia s.lat., 
TABLE 2

Description of Vegetation Groups (after Jarman et al. in prep.)

\begin{tabular}{|c|c|c|}
\hline $\begin{array}{l}\text { Group } \\
\text { number }\end{array}$ & Distribution & Remarks \\
\hline 1 & $\begin{array}{l}\text { Lowland, } \\
\text { mostly SW } \\
\text { Tas, also in } \\
\text { NW }\end{array}$ & $\begin{array}{l}\text { Open sandy or silty outwashes, including alkaline pans. Angiosperms sparse, } \\
\text { stunted. Common species include Actinotus suffocata, Baumea spp., Drosera arcturi } \\
\text { and } D \text {. spathulata (in NW). Gymnoschoenus depauperate. Mosses (Dicranoloma } \\
\text { billardieri) often dominant. Lichens rare or absent, confined to bases of shrubs. }\end{array}$ \\
\hline 2 & $\begin{array}{l}\text { Lowland, } \\
\text { throughout } \\
\text { Tas }\end{array}$ & $\begin{array}{l}\text { Usually flat, poorly drained sites on peat. Low density of angiosperms, } \\
\text { including Leptocarpus tenax, Lepyrodia tasmanica and Microlaena tasmanica. } \\
\text { Gymnoschoenus in large hummocks, forming a dense } \pm \text { pure stand, } \\
\text { sometimes with emergent shrubs. Lichens rare, } \pm \text { confined to rotting hummocks. }\end{array}$ \\
\hline 3 & $\begin{array}{l}\text { Lowland, } \\
\text { SW Tas }\end{array}$ & $\begin{array}{l}\text { Very wet, poorly drained facies of Group } 4 \text {. Angiosperms diverse, mostly as in Group } 4 \\
\text { but Winifredia sola, Oschatzia saxifraga and Baumea tetragona often present. } \\
\text { Gymnoschoenus common, in tufts. Lichens uncommon, mostly around shrub bases. }\end{array}$ \\
\hline 4 & $\begin{array}{l}\text { Lowland SW, } \\
\text { rare in NW }\end{array}$ & $\begin{array}{l}\text { Most common and widespread vegetation type in } \mathrm{SW} \text { Tas, occurring on peat. } \\
\text { Angiosperms diverse, include Leptospermum nitidum, Melaleuca squamea, } \\
\text { Baeckea leptocaulis, Boronia pilosa, Epacris corymbiflora, Restio mono cephalus and } \\
\text { Actinotus bellidioides. Gymnoschoenus common. Lichens common in clearings. } \\
\text { Additional species present on small, loose stones. }\end{array}$ \\
\hline 5 & $\begin{array}{l}\text { High } \\
\text { altitude } \\
\text { SW Tas }\end{array}$ & $\begin{array}{l}\text { Often dense, shrubby or sedgy communities on peat. Angiosperms include } \\
\text { Epacris heteronema, Isophysis tasmanica, Dracophyllum milliganii and } \\
\text { Eucalyptus vernicosa.Gymnoschoenus usually in large hummocks. Lichens locally } \\
\text { abundant on rotting hummocks or in small, stony clearings where Donatia novae- } \\
\text { zelandiae, Oreobolus spp., Lepidosperma inops and Pentachondra pumila occur. }\end{array}$ \\
\hline 6 & $\begin{array}{l}\text { Lowland, } \\
\text { SW Tas }\end{array}$ & $\begin{array}{l}\text { Heathlands or copses on well-drained peaty soil. Common angiosperms include } \\
\text { Eucalyptus nitida, Leptospermum scoparium, Dillwynia glaberrima, Boronia } \\
\text { citriodora and Monotoca submutica. Gymnoschoenus absent or poorly developed, often } \\
\text { dying. Lichens common in small clearings, particularly where wombats (Vombatus } \\
\text { ursinus) graze, on rotting stumps or decaying hummocks. Similar copses dominated } \\
\text { by Melaleuca squarrosa occur in wet, poorly drained sites but are depauperate } \\
\text { lichenologically. }\end{array}$ \\
\hline
\end{tabular}
outside SW, mainly on Central Plateau

Heathland communities with many angiosperms, including Hibbertia procumbens, Tetratheca procumbens, Coprosma moorei, Poa gunnii, Pentachondra pumila and Leucopogon sp. Gymnoschoenus uncommon, in sparse tufts.

Lichens on peat, usually common, especially in clearings between shrubs. outside SW Tas

Shrubby communities, mostly on well-drained slopes. Common angiosperms include Leptospermum scoparium, Epacris impressa, Aotus ericoides, Hibbertia procumbens, Dillwynia glaberrima and Leucopogon collinus. Gymnoschoenus uncommon. Lichens usually abundant, especially on peat in clearings between shrubs. 


$\begin{array}{ll}\text { ment Distribution } & \text { Remarks } \\ \text { nerer } & \end{array}$

10 High altitude, Central Plateau and NE

Highlands

11 Lowland, outside SW Tas

12 High altitude, Central Plateau and NE Highlands
Sedgy communities, probably derived from raised bogs (type 9) which have been degraded by frequent burning. Common angiosperms include Restio australis, Diplarrena latifolia, Lepyrodia tasmanica and Xyris spp. Gymnoschoenus common, in crowded hummocks. Lichens local in clearings between sedges or on dead hummocks.

Sedgy, poorly drained communities. Common angiosperms include Melaleuca squarrosa, Epacris lanuginosa, Leptocarpus tenax, Lepyrodia tasmanica, Xyris operculata and Baumea rubiginosa. Gymnoschoenus dense. Lichens rare, \pm confined to dead hummocks. This vegetation is usually young and may be very frequently burnt (possibly at 3-4 year cycles) but older vegetation may be scrubby with tall Melaleuca squarrosa and Leptospermum scoparium and prominent lichens on peat.

Grassy and herbaceous communities, often abutting buttongrass moorland. Angiosperms include Poa spp., Astelia alpina, Olearia spp., Helichrysum spp., Galium australe, Geranium potentilloides and Wahlenbergia sp. Gymnoschoenus rare, in large hummocks. Lichens \pm absent.

TABLE 3

\title{
Description of Lichen Groups
}

\author{
Group \\ Remarks \\ number
}

1 Ubiquitous species, occurring in most buttongrass moorland. However, Cladonia subsubulata is most abundant in heathy communities outside southwestern Tasmania.

2 Species confined to southwestern Tasmania.

3 Species mostly found at high altitude in southwesternTasmania, although Cladia fuliginosa and Cladina mitis also occur on high mountains elsewhere in other vegetation types, e.g. feldmark. The altitudinal range of Wawea fruticulosa is wider where it occurs as an epiphyte in forest or scrub.

4 Species characteristic of buttongrass moorland in southwestern Tasmania, but extending into high altitude communities elsewhere in Tasmania. Cladia sullivanii is more widely distributed in other vegetation formations (heathland and open forest).

$5 \quad$ Species widespread in heathlands and shrubby buttongrass moorland.

6 Species found mostly in high altitude buttongrass moorland outside southwestern Tasmania. Some, e.g. Trapeliopsis colensoi, are present in the southwest but in other vegetation.

7 Species found mostly in lowland buttongrass moorland outside southwestern Tasmania, also characteristic of sclerophyll forest, particularly in eastern Tasmania. 
Umbilicaria and Hypogymnia occur on rock outc rops. In addition, pairs of related species or genera occur in similar habitats, e.g. Parmelia saxatilis, Icmadophila ericetorum, Pycnothelia papillaria and Cladonia subulata in Britain, Parmelia signifera, Knightiella splachnirima, Pycnothelia caliginosa and Cladonia corniculata respectively in Tasmania.

Approximately $25 \%$ of the species recorded in Tasmanian buttongrass moorland are cosmopolitan or bipolar and hence common to both regions, e.g. Cladonia cervicornis ssp. verticillata, $C$. chlorophaea, $C$. pleurota, $C$. ochrochlora, $C$. pyxidata, C. rei, Cystocoleus niger, Hypotrachyna sinuosa, Multiclavula vernalis, Ochrolechia frigida, Protoblastenia rupestris and Rhizocarpon cf. geographicum. However, many additional characteristic British blanket bog species (see James 1965, Gilbert 1972, 1974, 1980b), e.g. Coelocaulon aculeatum, Alectoria nigricans, Pseudephebe pubescens, Trapeliopsis granulosa and Thamnolia vermicularis also occur in Tasmania, but in related heathland, feldmark and other treeless vegetation at higher altitudes than those characteristic of buttongrass moorland. It is possible that these species may have been eliminated from lower altitudes (and hence buttongrass moorland) in Tasmania by repeated fires in the past.

Several ecological similarities are also evident between the Tasmanian and Northern Hemisphere vegetation. For example, the occurrence of alpine lichens to sea level in northern Scotland (Fletcher 1984) and Norway (P. M. Jørgensen, pers. comm.) is analogous to the situation in southwestern Tasmania. In both Tasmania and Britain, lichens are relatively impoverished in intact blanket bogs and heathlands. In Britain, they proliferate locally on track sides or peat banks and overhangs caused by erosion (Gilbert 1972, 1980a) and they are often best developed in similar situations in Tasmania.

\section{SUMMARY}

Buttongrass moorland occupies approximately $15 \%$ of the area of Tasmania. It contains a primarily terricolous lichen flora, occurring mostly on peat, dominated by the genera Cladia, Cladonia, Siphula and Cladina. Many additional species occur on large rock outcrops, loose stones and on emergent trees and shrubs which form a common feature of the moorland landscape.

Over $70 \%$ of the 89 lichens recorded from buttongrass moorland have essentially Southe Hemisphere distributions, analogous to th majority of the vascular flora. However, very few species are endemic. Several parallels are evident between Tasmanian buttongrass moorland and ecologically related blanket bogs and moors in the Northern Hemisphere. In addition to many generic similarities, approximately $25 \%$ of Tasmania's moorland lichens also occur in the Northern Hemisphere.

Most lichens in buttongrass moorland occur in well-drained, well-lit habitats and are best developed in shrubby communities or at high altitude. Favoured habitats include peat banks in clearings, decaying Gymnoschoenis hummocks and rotting stumps. Communities where the vascular plant cover is very dense or where the ground is boggy or periodically inundated are lichenologically depauperate.

For the most part fire has a disastrous effect on the lichen flora of buttongrass moorland, both directly and by destroying habitats and substrates, particularly peat. The outcome of repeated fires is likely to be similar to that found in Britain in analogous vegetation, with a severe loss of diversity and reduction of the flora to a few, impoverished thalli of ubiquitous, rapidly colonising species. Frequent and indiscriminate burning of Tasmania's buttongrass moorland could lead to the local extinction of many species.

\section{ACKNOWLEDGEMENTS}

We thank Dr A. W. Archer, Dr M. J. Brown, Dr J. A. Elix, Ms J. Johnston and Prof. P. M. Jørgensen for their critical comments on the manuscript, and Dr A. W. Archer, Dr B. J. Coppins, Dr J. A. Elix, Prof. H. Hertel, Mr P. W. James and Dr A. Vezda for assistance with lichen identifications. The use of laboratory facilities at the Botany Department, University of Tasmania, is gratefully acknowledged. The study was supported jointly by the Forest Ecology Research Fund, Lands Department, Tasmanian Fire Service, National Parks and Wildlife Serivce and Forestry Commission.

\section{REFERENCES}

ARCHER, A.W., 1983: Cladonia chlorophaea sens. lat. in southeastern Australia. Bryologist 86: $251-253$. 
ARCHER, A.W., 1986: The chemistry and distribution of Cladonia capitellata (J.D. Hook. \& Taylor) Church. Bab. (Lichenes) in Australia. Proc. Linn. Soc. N.S.W. 108: 191-194.

BRATT, G.C., 1976: Lichens of South West Tasmania I. Lichens of the buttongrass areas. Tasm. Naturalist 45: 1-4.

BRATT, G.C., 1978: Mosses and lichens. In Sharp-Paul, A. (Ed.): LOWER GORDON RIVER SCIENTIFIC SURVEY. Hydro-Electric Commission, Hobart: 1-24.

BROWN, M.J., CROWDEN, R.K. \& JARMAN, S.J., 1982: Vegetation of an alkaline pan-acidic peat mosaic in the Hardwood River Valley, Tasmania. Aust. J. Ecol. 7: 3-12.

COPPINS, B.J. \& SHIMWELL, D.W., 1971: Cryptogam complement and biomass in dry Calluna heath of different ages. Oikos 22: 204-209.

DUNCAN, F., 1985: In ENVIRONMENTAL IMPACT STATEMENT ON TASMANIA'S WOODCHIP EXPORTS BEYOND 1988. WORKING PAPER 6. Tasmanian Forestry Commission, Hobart.

FLETCHER, A., 1984: Conservation of terricolous lichens in Britain. Brit. Lich. Soc. Bull. 55: 1-4.

FOSTER, D.R., 1984: The dynamics of Sphagnum in forest and peatland communities in southeastern Labrador, Canada. Arctic 37: 133-140.

GALLOWAY, D.J., 1979: Biogeographical elements in the New Zealand lichen flora. In Bramwell, D. (Ed.): PLANTS AND ISLANDS. Academic Press, London: 201-224.

GELLIE, N.J.H., 1980: Fire ecology of buttongrass moorlands. For. Comm. Tasm. Bull. 6.

GILBERT, O.L., 1972: Field Meeting in Northumberland. Lichenologist 5: 337-341.

GILBERT, O.L., 1974: Reindeer grazing in Britain. Lichenologist 6: 165-167.

GILBERT, O.L., 1980a: Effect of land-use on terricolous lichens. Lichenologist 12: 117-124.

GILBERT, O.L., 1980b: A lichen flora of Northumberland. Lichenologist 12: 325-395.

GIMINGHAM, C.H., 1960: Biological flora of the British Isles. Calluna Salisb. J. Ecol. 48: $455-483$.

GIMINGHAM, C.H., 1978: Calluna and its associated species: some aspects of co-existence in communities. Vegetatio 36: 179-186.
HAWKSWORTH, D.L., 1969: The lichen flora of Derbyshire. Lichenologist 4: 105-193.

HOBBS, R.J., 1985: The persistence of Cladonia patches in closed heathland stands. Lichenologist 17: $103-109$.

JACKSON, W.D., 1968: Fire, air, earth and water - an elemental ecology of Tasmania. Proc. Ecol. Soc. Aust. 3: 9-16.

JAMES, P.W., 1965: Field Meeting in Scotland. Lichenologist 3: 155-172.

JARMAN, S.J., KANTVILAS, G. \& BROWN, M.J., in prep.: BUTTONGRASS MOORLAND IN TASMANIA. National Parks and Wildlife Service, Hobart.

JØRGENSEN, P.M., 1983: Distribution patterns of lichens in the Pacific region. Aust. J. Bot. Suppl. 10: $43-66$.

KANTVILAS, G., 1987: Siphula jamesii, a new lichen from south-western Tasmania. Nord. I. Bot. 7: $585-588$.

KANTVILAS, G. \& ELIX, J.A., 1987: A new species of Cladia (Lichenised Ascomycotina) from Tasmania. Mycotaxon 29: 199-205.

KANTVILAS, G., JAMES, P.W. \& JARMAN, S.J., 1985: Macrolichens in Tasmanian rainforests. Lichenologist 17: 67-83.

KIRKPATRICK, J.B. \& DICKINSON, K.J.M., 1984: VEGETATION MAP OF TASMANIA. Forestry Commission, Hobart.

PETERSON, R.H. \& KANTVILAS, G., 1986: Three lichen-forming Clavarioid fungi from Tasmania. Aust. J. Bot. 34: 217-222.

TARVYDAS, R., 1978: Soils. In Sharpe-Paul, A. (Ed.): LOWER GORDON RIVER SCIENTIFIC SURVEY. Hydro-Electric Commission, Hobart.

WATSON, W., 1932: The bryophytes and lichens of moorland. J. Ecol. 20: 284-313.

WALKER, F.J., 1985: The lichen genus Usnea subgenus Neuropogon. Bull. Br. Mus. Nat. Hist. (Bot.). 13: $1-130$.

WETMORE, C.M., 1963: Catalogue of the lichens of Tasmania. Rev. Bryol. et Lichenol. 32: 223-264.

(accepted 15 April, 1987) 


\section{APPENDIX}

This appendix lists the 89 lichens which were recorded during the survey. Supplementary notes relate mainly to the occurrence of the species in buttongrass moorland but this has been placed into a broader Tasm anian context where the information is available. Genera where additional, unidentified species are known (or expected) are also indicated. These are mainly the saxicolous crustose groups.

(1) Baeomyces arcuatus Stirton: referred to as $B$. fungoides (Sw.) Ach. in Australasian literature; common and widespread in Tasmania on mineral soil; densely sorediate, sterile thalli are occasional on clay soils in buttongrass moorland; contains baeomycesic and squam atic acids.

(2) Catillarias.Jat. sp.:very common on decorticated, dead eucalypt stumps and trunks in copses or heathlands in buttongrass moorland; the species has an evanescent thallus and abundant, irregularly roundish, black, lecideine apothecia, to c. $1 \mathrm{~mm}$ diam.; spores are hyaline, very inconspicuously 1 -septate, oblong to narrow ellipsoid, $7-12 \times 2.5-5 \mu \mathrm{m}$.

(3) Cladia aggregata (Sw.) Nyl.: very common, highly polymorphic species found on soil, peat or rotting wood in virtually all vegetation formations in Tasmania; contains barbatic, stictic, norstictic or fumarprotocetraric acids.

(4) Cladia fuliginosa R. Filson: common on peat in alpine vegetation, rare in buttongrass moorland and confined to high altitude communities.

(5) Cladiainflata(F. Wilson) D. Galloway: common on wet, poorly drained peat and soil in heathlands and sedgelands from sea level to alpine altitudes, particularly in western Tasmania; contains fumarprotocetraric or fatty acids.

(6) Cladiamoniliformis Kantvilas \& Elix: endemic; common on very wet peat or mineral soil in buttongrass moorland in southwestern Tasmania from sea level to alpine altitudes (see Kantvilas \& Elix 1987); contains homosekikaic acid.

(7) Cladia retipora (Labill.) Nyl.: very common and widespread on peat and soil in sedgelands, heathlands and open forests, from sea level to alpine altitudes.

(8) Cladia schizopora (Nyl.) Nyl.: confined to rotting, often charred wood, mostly in eucalypt forest; rare in buttongrass moorland.

(9) Cladia sullivanii (Müll. Arg.) Martin: very common and widespread on peat and soil in heathlands from sea level to alpine altitudes.
(10) Cladina confusa (R. Sant.) Follm. \& Ahti common and widespread on peat and soil in heathlands and forests, particularly at high altitudes; the species contains perlatolic and usnic acids but specimens from very shaded habitats contain very low concentrations of the latter and are grey in colour.

(11) Cladina mitis (Sandst.) Hustich: common on peat or over microshrubbery in alpine vegetation, occasional in high altitude buttongrass moorland; all Tasmanian specimens contain usnic and stictic acids.

(12) Cladonia angustata Nyl.: uncommon on welldrained fibrous peat in lowland heathland communities in southern, eastern and northern Tasmania; contains usnic and didymic acids.

(13) Cladonia campbelliana (Vainio) Gyelnik: widespread on well-drained peat, rotten wood or (rarely) mineral soil in heathlands and sclerophyll forests from sea level to subalpine altitudes; contains fumarprotocetraric acid.

(14) Cladonia capitellata (J.D. Hooker \& Taylor) Church. Bab.: very common and widespread in sedgelands, heathlands and sclerophyll forests from sea level to alpine altitudes, often forming extensive mats on peat, mineral soil or in litter-filled rock crevices; three chemical races occur in Tasmania (Archer 1986): var. capitellata (containing usnic and thamnolic acids), var. squamatica Archer (containing usnic and squamatic acids) and var. interhiascens (Nyl.) Sandst. (containing usnic acid only); all but the last were recorded from buttongrass moorland; a form of var. squamatica which lacks usnic acid is locally common at Mathinna Plains in northeastern Tasmania.

(15) Cladoniacervicornis subsp.verticillata (Hoffm.) Ahti: very common and widespread on soil and peat in open forests and heathlands throughout Tasmania; extremely polymorphic; contains fumarprotecetraric acid.

(16) Cladonia chlorophaea (Flörke ex Sommerf.) Sprengel aggr:: widespread on peat or soil along roadsides or in forests or heathlands, uncommon in buttongrass moorland; three chemical strains were recorded during the survey: $C$. chlorophaea s.str. 
(fumarprotocetraric acid), C. cryptochlorophaea Asah. (cryptochlorophaeic acid) and $C$. merochlorophaea Asah. (merochlorophaeic, 4-0-methyl-cryptochlorophaeic, \pm fumarprotocetraric acids); of these C. merochlorophaea appears to be the most common (cf. Archer 1983); all three chemotypes may occur at a single locality.

(17) Cladonia corniculata Ahti \& Kashiwadani: widespread and common on peat or mineral soil in heathlands and open forests throughout Tasmania, uncommon in buttongrass moorland; previously erroneously referred to in Tasmanian literature as C. subulata (L.) Wigg.; contains fumarprotocetraric acid.

(18) Cladonia gracilis subsp. tenerrima Ahta: uncommon in buttongrass moorland and found mainly in sclerophyll forest and scrub; contains fumarprotocetraric acid.

(19) Cladonia kuringaiensis Archer: uncommon in Tasmania and found on peat or rotting wood in heathlands or at the margins of forests; contains fumarprotocetraric and stictic acids.

(20) Cladonia murrayi W. Martin: widespread on peat and soil, usually at high altitudes in southwestern Tasmania; below c. $600 \mathrm{~m}$, the species usually occurs as squamules only; contains thamnolic acid and skyrin.

(21) Cladonia ochrochlora Flörke: very polymorphic species, widespread on peat, rotten wood, litter and soil in heathlands and wet forests; contains fumarprotocetraric acid.

(22) Cladoniapleurota (Flörke) Schaerer: widespread in Tasmania on soil and peat, particularly at high altitudes; uncommon in buttongrass moorland and confined to shrubby communities or soil-filled crevices in large rock outcrops; contains usnic and isousnic acids and zeorin.

(23) Cladoniapraetermissa Archer: locally abundant in the eastern half of Tasmania, mostly in lowland dry eucalypt forest; uncommon in buttongrass moorland and confined to shrubby communities; contains atranorin and fumarprotocetraric acid.

(24) Cladonia pyxidata (L.) Hoffm.: wide-ranging but uncommon on peat or mineral soil in heathland and open forest; contains fumarprotocetraric acid.

(25) Cladonia ramulosa (With.) Laundon: uncommon but widespread in wet heathlands and open forests on peaty soil; contains fumarprotocetraric acid.
(26) Cladonia rei Schaerer:apparently rare, at least in buttongrass moorland, and recorded only once during the survey (from Cox Bight, southwestern Tasmania); contains fumarprotocetraric and homosekikaic acids.

(27) Cladonia scabriuscula (Delise) Nyl.: common and widespread on peat, soil or litter in wet forests, rare in buttongrass moorland; contains fumarprotocetraric acid.

(28) Cladonia southlandica Martin: most common species of Cladonia found in buttongrass moorland, occurring on peat or rotting Gymnoschoenus hummocks in most communities from sea level to alpine altitudes; it is a rapid coloniser of scorched or burnt peat and is often found only as extensive mats of squamules; contains usnic and fumarprotocetraric acids.

(29) Cladonia squamosula Müll. Arg.: very common and widespread throughout Tasmania on rotting wood or (rarely) peat; locally abundant in buttongrass moorland on eucalypt stumps in heathland and copses; contains thamnolic acid, with barbatic acid in the apothecia.

(30) Cladonia subdigitata Nyl.: occasional on rotting wood and peat in buttongrass moorland, wet heathland, scrub and forest; contains usnic and thamnolic acids, and skyrin.

(31) Cladonia subsubulata Nyl.: very polymorphic, widespread species of buttongrass moorland, heathland and open forest; high altitude forms have slender, entangled podetia, \pm dying at the base and lacking squamules; in the lowlands, the species usually has stouter, corymbose podetia, arising from a mat of squamules; contains thamnolic acid, with barbatic acid in the apothecia.

(32) Cladonia tessellata Ahti \& Kashiwadani: uncommon on peat or mineral soil in heathlands or at forest margins; earlier records of $C$. capitata and $C$. cariosa from Tasmania probably refer to this species; contains fumarprotocetraric acid.

(33) Cladonia weymouthii F. Wilson ex A. Archer: common and widespread on peat and rotting wood in heathland and buttongrass moorland, mostly in western Tasmania; similar to $C$. corniculata but containing thamnolic, barbatic and didymic acids.

(34) Cladonia wilsonii A. Archer: rare but widespread on peat, soil or rotting wood in heathlands and wet forests; usually encountered as basal squamules only; contains atranorin and stictic acid. 
(35) Cystocoleus niger (Huds.) Hariot: common in sheltered microhabitats on large rock outcrops in heathland and buttongrass moorland, mostly in south western Tasmania.

(36) Flavoparmelia haysomii (Dodge) Hale: abundant on large rock outcrops in buttongrass moorland, heath lands and open eucalypt forest, usually associated with $P$. signifera, Xanthoparmelia spp. and Usnea torulosa; the species most probably represents what has been referred to as Parmelia caperata in earlier Tasmanian literature.

(37) Gymnoderma melacarpum (F. Wilson) Yoshimura: common in Tasmania in wet forests on Eucalyptus bark, wood or litter; a distinctive form occurs in peat-filled rock crevices on quartzite outcrops in but tongrass moorland abovec. $600 \mathrm{~m}$ in southwestern Tasmania; this form has terete, \pm radially symmetric olive-brown squamules, densely packed to form \pm rounded cushions, and rather resembles a diminutive Sphaerophorus.

(38) Hacmatommainfuscum (Stirton ex Bailey) R.W. Rogers: widespread wet forest twig species, occasional in high altitude buttongrass moorland on emergent Casuarina, Baeckea and other shrubs.

(39) Heterodermia microphylla (Kurok.) Swinsc. \& Krog: locally common and widespread on rocks or (rarely) trees) in lowland, coastal heathlands and open forests; rare in buttongrass moorland; contains atranorin and terpenes.

(40) Heterodermia obscurata (Nyl.) Trevisan: uncommon, mostly on quartzite outcrops in coastal vegetation, association with $H$. microphylla.

(41) Hypocenomyce australis Timdal: a new record for Tasmania; common in dry sclerophyll forest but rare in buttongrass moorland and confined to charred wood of Eucalyptus, Bacckea and other Myrtaceae.

(42) Hypogymnia lugubris (Pers.) Krog: widespread and common, mostly at high altitudes, on trees, shrubs, large rock outcrops or over peat, litter and microshrubbery.

(43) Hypogymnia turgidula (Bitter) Elix: widespread and very common, mostly in wet forests; found in buttongrass moorland on emergent trees and shrubs.

(44) Hypotrachyna sinuosa (Sm.) Hale: widespread on trees or rocks in well-lit habitats in wet forests and heathlands.
(45) Knightiellasplachnirima(J.D. Hooker\& Taylor) Gyelnik: widespread but most abundant in southwestern Tasmania, on moist, peaty soil in buttongrass moorland, heathland and clearings in wet sclerophyll forest, from sea level to high mountain summits.

(46) Lecidea coromandelica Zahlbr:: saxicolous, mostly in high altitude heathlands and buttongrass moorlands, extending to sea level on Precambrian rocks in southwestern Tasmania.

(47) Lecidea laeta Stirton: very abundant throughout Tasmania in well-lit, corticolous habitats in heathland, sclerophyll forest and rainforest; found in buttongrass moorland on iwigs of emergent shrubs, particularly Melaleuca, Leptospermum and Baeckea.

(48) Lecidea leptocarpa Nyl. in Church. Bab. \& Mitten aggr.: wide-ranging and polymorphic species on rocks throughout Tasmania. Very common in buttongrass moorland on large outcrops as well as small, loose pebbles; the \pm contiguous, black apothecia are sometimes responsible for the black streaks on white quartzite boulders; additional species of Lecideaceae s.lat. have been recorded from Precambrian metamorphic rocks and limestone in buttongrass moorland but will be reported separately.

(49) Lecidella elaeochroma (Ach.) M. Choisy: very common on twigs and trunks in high rainfall areas from sea level to alpine altitudes; often the most common epiphyte of emergent trees and shrubs (particularly Banksia) in buttongrass moorland.

(50) Lithographa sp.: first record of the genus for Australia; uncommon and apparently confined to southwestern Tasmania on small, loose quartzite stones on gravelly slopes in buttongrass moorland; the species has an endolithic thallus and hyaline, $15-17 \times 8-8.5 \mu \mathrm{m}$ spores.

(51) Menegazzia aeneofusca (Müll. Arg.) R. Sant.: widespread on large rock outcrops, mosily at subalpine and alpine altitudes, but extending to sea level in sheltered habitats, particularly in southwestern Tasmania; typically recognised by the dark olive-brown or blackened upper cortex but thalli from exposed habitats may be bleached pale greenish grey.

(52) Menegazzia confusa P. James: local in dry sclerophyll forest; uncommon in buttongrass moorland and recorded from emergent shrubs in lowland, coastal communities; closely related to $M$. platytrema and differing chiefly by the presence of fatty acids instead of stictic acid in the medulla. 
(53) Mengazzia platytrema (Müll. Arg.) R. Sant.: widespread in well-lit habitats in rainforest and sclerophyll forest; the most common epiphytic Menegazzia in buttongrass moorland, occurring on Banksia, Hakea and other shrubs; additional species of Menegazzia, e.g. M. subbullata, $M$. subpertusa and $M$. weindorferi, may also occur in buttongrass moorland near wooded or scrubby margins, at high altitude or on occasional, old, fire-protected trees.

(54) Micarea sp.nov.: a new species, endemic to Tasmania and related to $M$. ternaria from the Northern Hemisphere (B.J. Coppins, pers. comm.); widespread in southwestern Tasmania from sea-level to high mountain summits in buttongrass moorland, heathland and feldmark; the species acts as a stabiliser of peat and soil on very open, gravelly slopes and is usually associated with Siphula jamesii and $S$. decumbens.

(55) Multiclavula vernalis (Schw.) Petersen: a new record for Tasmania (see Petersen \& Kantvilas 1986); locally abundant in buttongrass moorland in southwestern Tasmania on moist soil along streams, drainage channels and tracks, on muddly flats between Gymnoschoenus hummocks and on raised earth turrets built by lobsters (e.g. Parastacoides spp.).

(56) Neofuscelia stygioides (Nyl. ex Crombie) Esslinger = Parmelia stygioides Nyl. ex Crombie: widespread, essentially alpine, saxicolous species, occasional in buttongrass moorland on large rock outcrops, mostly in southwestern Tasmania.

(57) Ochrolechia frigida (Sw.) Lynge: new record for Tasmania; widespread in alpine moorland and heathland over soil and microshrubbery; rare in buttongrass moorland and confined to high altitude communities in southwestern Tasmania.

(58) Omphalina sp.: locally abundant and widespread on moist, peaty soil in many buttongrass moorland, heathland and sclerophyll forest communities, often fruiting most prolifically soon after a fire; the species has a granular, Botrydina-type thallus.

(59) Parmeliasignifera Nyl.: very common and widespread on large rock outcrops, particularly at high altitudes; frequently becoming blackened on the upper surface with conspicuous white sigmoid pseudocyphellae.

(60) Peltigera dolichorhiza (Nyl.) Nyl.: common on the forest floor, logs and tree buttresses in wet forests; rare in buttongrass moorland and confined to shaded habitats in copses.
(61) Pertusaria sp:: most probably a new species with a thick, pale yellow thallus containing usnic and gyrophoric acids and pale red-brown spores, $100-210 \times 45-90 \mu \mathrm{m}, 1$ per ascus; common in southwestern Tasmania in open, heathy vegetation above c. $700 \mathrm{~m}$ where it forms a crust over peat, litter and low shrubs, e.g. Donatia and Pentachondra; fertile material is rare.

(62) Placopsis trachyderma var. clavifera (Lamb) P. James: uncommon, recorded from fresh clay at the margin of buttongrass moorland in southwestern Tasmania; additional species of Placopsis (e.g. $P$. parellina, $P$. gelida) occur in the vicinity of buttongrass moorland along roadsides on clay and stones but the genus has not been recorded from peat and is rare in this vegetation type; in Tasmania, Placopsis is most common and diverse in subalpine or alpine heathlands and boulder fields but is still very poorly known.

(63) Placynthium nigrum (Huds.) S.F. Gray: new record for Tasmania; restricted to limestone and locally abundant in buttongrass moorland in southwestern Tasmania.

(64) Protoblastenia rupestris (Scop.) Steiner: new record for Tasmania; rare and recorded only from limestone outcrops in buttongrass moorland near the Maxwell River, southwestern Tasmania.

(65) Protoparmelia petraeoides (Nyl. ex Hue) Hertel: widespread on rocks throughout Tasmania, common in buttongrass moorland on large outcrops, associated with Lecidea leptocarpa, Xanthoparmelia spp. and Parmelia signifera.

(66) Pycnotheliacaliginosa D. Galloway \& P. James: local on mountains in southwestern Tasmania and recorded in buttongrass moorland from peat-filled rock crevices, decomposing Gymnoschoenus hummocks or Donatia bolsters, and from moist sandy soils; associated species include Siphula decumbens, S. jamesii, Cladia spp., Micarea sp., Cladina mitis, Cladonia southlandica and $C$. murrayi.

(67) Rhizocarpon cf. geographicum (L.) DC.: widespread on rocks, especially at high altitude; locally abundant in buttongrass moorland on large outcrops, associated with species of Lecideaceae and Xanthoparmelia.

(68) Siphula complanata (J.D. Hooker \& Taylor) R. Sant.: local in alpine moors and heathlands, usually on very wet, periodically inundated peaty soil; occasional in buttongrass moorland at its upper altitudinal limits; 
contains porphyrilic acid and methyl porphyrilate; a related, undescribed species, containing porphyrilic acid only, occurs in dry, peat-filled rock crevices in alpine quartzite rock outcrops in southwestern Tasmania

(69) Siphula decumbens Nyl.: the most common Siphula in Tasmania, recorded on peat or mineral soil in buttongrass moorland in southwestern Tasmania and in alpine vegetation on high mountains elsewhere; lobe morphology is extremely variable, ranging from loose, narrow and straplike (in shaded sites beneath shrubs or sedges) to crowded, short and rounded (in exposed habitats); the species commonly forms extensive chalky white swards and associated lichens include Cladia aggregata, $C$. retipora, Cladonia southlandica, $C$. murrayi and Siphula jamesii; contains thamnolic acid (thallus $\mathrm{K}+$ yellow).

(70) Siphulafragilis (J.D. Hooker \& Taylor) J. Murray: widespread on muddy soil in or around shallow pools on high mountain plateaux; uncommon in buttongrass moorland and confined to high altitude communities; contains no substances detectable by TLC.

(71) Siphula jamesii Kantvilas: common on exposed, very wet peat or mineral soil, particularly on bare gravelly slopes in buttongrass moorland, feldmark and heathland from sea-level to alpine altitudes in southwestern Tasmania (Kantvilas 1987); associated species include $S$. decumbens, Cladiamoniliformis and Micarea sp.nov.; contains no substances detectable by TLC.

(72) Siphulastrum triste Müll. Arg.: new record for Tasmania; uncommon or overlooked, amongst mosses on rock outcrops in alpine and subalpine vegetation; rare in buttongrass moorland.

(73) Sphaerophorus tener Laurer: the most widespread and common species of the genus, occurring in rainforest, wet scrub, heathland and alpine vegetation; in buttongrass moorland, it is restricted to high altitude rock outcrops or heathy communities where it overgrows bryophytes and low shrubs; saxicolous individuals are extremely polymorphic and forms which are tufted or where the lateral branches are eroded may have been previously misidentified as $S$. fragilis or $S$. globosus, species recorded from Tasmania in the 19th century (Wetmore 1963) but not found subsequently; additional Sphaerophorus species, e.g. S. melanocarpus and S. ramulifer, may also occur in sheltered microhabitats on rock outcrops in high altitude vegetation.

(74) Stereocaulon ramulosum (Sw.) Räuschel: widespread on rocks throughout Tasmania in open forests, heathlands, alpine vegetation and along roadsides; uncommon in buttongrass moorland and found mostly in high altitude communities.

(75) Thysanothecium scutellatum (Fr.) D. Galloway $=T$. hyalinum (Taylor) Nyl.: common in dry sclerophyll forest on eucalupt charcoal or wood, associated with Cladia schizopora and Cladonia squamosula; rare in buttongrass moorland and confined to low land coastal communities in northern and eastern Tasmania

(76) Trapeliopsis colensoi (Church. Bab.) G. Schneider: new record for Tasmania; locally common on exposed banks of peat or sandy soil in clearings, along tracks or on rotting Gymnoschoenus hummocks, in heathlands or open sclerophyll forest; recorded mostly above c. $700 \mathrm{~m}$ in the Central Highlands.

(77) Umbilicaria cylindrica (L.) Delise in Duby: common and widespread on alpine and subalpine rocks, extending to sea-level on quartzite boulders in buttongrass moorland in southwestern Tasmania; associated species include Usnea torulosa, Parmelia signifera and Xanthoparmelia spp.

(78) Umbilicaria polyphylla (L.) Baumg.: locally common on quartzite outcrops in southwestern Tasmania in alpine and subalpine vegetation or in buttongrass moorland abovec. $600 \mathrm{~m}$; associated species include U.cylindrica, Neofuscelia stygioides, Parmelia signifera and Xanthoparmelia spp.

(79) Usnea arida Motyka: very polymorphic; the most common corticolous $U_{s n e a}$ in high rainfall regions of Tasmania, occurring in buttongrass moorland on emergent shrubs of Banksia, Hakea and Casuarina, associated with Hypogymnia and Menegazzia spp.; thalli from exposed, windswept habitats are often very inflated and lack lateral branches; contains usnic and salazinic acids.

(80) Usnea torulosa (Müll. Arg.) Zahlbr. $=U$ glomerata Motyka: widespread and common on rocks throughout Tasmania; all populations studied from buttongrass moorland contain barbatic acid, a chemical strain reported by Walker (1985) as being the least common; psoromic and squamatic acid strains also occur in Tasmania but appear to be confined to high mountains; in exposed habitats, the species may be partially blackened and resemble a Neuropogon.

(81) Waweafruticulosa Henssen \& Kantvilas: locally abundant throughout western Tasmania in wet forest, heathland and scrub; uncommon in buttongrass moorland and confined to moist peat in some high 
altitude communities, or to the papery bark of Leptospermum or Melaleuca in wet copses.

(82) Xanthoparmeliaadhaerens (Nyl.) Hale: common on Precambrian rock outcrops in buttongrass moorland in southwestern Tasmania, also recorded elsewhere in the island; usually associated with $X$. mougeotina; contains usnic and stictic acids (major substances)

(83) Xanthoparmelia alexandrensis Elix \& Johnston: apparently rare and known from a single locality near Mt Tyndall, western Tasmania, where it occurs on conglomerate boulders in buttongrass moorland; contains usnic and norstictic acids (major substances).

(84) Xanthoparmelia amplexula (Stirton) Elix \& Johnston: widespread on rock outcrops in buttongrass moorland, heathland and sclerophyll forest, usually associated with other Xanthoparmelia spp.; contains usnic acid, norlobaridone and loxodin.

(85) Xanthoparmelia isidiigera (Müll. Arg.) Elix \& Johnston: widespread on rock outcrops throughout
Tasmania; contains usnic and salazinic acids (major substances).

(86) Xanthoparmeliamougeotina(Nyl.) D. Galloway: very common throughout Tasmania on stones and large rock outcrops; contains usnic and stictic acids (major substances).

(87) Xanthoparmelia neotinctina (Elix) Elix \& Johnston: widespread on rocks in Tasmania, particularly in drier areas but uncommon in buttongrass moorland; contains usnic and norstictic acids (major substances).

(88) Xanthoparmelia scabrosa (Taylor) Hale: local on rock outcrops, particularly at high altitudes; contains usnic acid, norlobaridone and loxodin.

(89) Xanthoparmelia tegeta Elix \& Johnston: widespread in Tasmania and locally common on Precambrian outcrops in buttongrass moorland in southwestern Tasmania; contains usnic and stictic acids (major substances) 